\title{
Of Bridges and Borders: An APSA Congressional Fellow's North American Tale
}

\author{
Matthew K. Asada
}

T had seen once before, halfway around the world, what a new bridge could do to a border region. However, despite having worked in border towns and on border issues for more than a decade, I had never given much thought to the border in my own backyard. I remember crossing the Detroit River to visit the casinos in Windsor, Ontario, before Detroit had her own and seeing the lines of trucks waiting to cross the bridge and being unaware of the border's economic importance to the region and the country. I had studied the economic benefits of European integration, but never thought about how those lessons could be applied to the North American continent. However, last year as a 2011-2012 APSA congressional fellow working with my hometown congressman US Representative Gary Peters I had the opportunity to apply these overseas experiences to a border that mattered to my town, state, and country. The US-Canadian border is not only the world's longest nonmilitarized border, but is also the line separating my hometown Detroit, Michigan, from Windsor, Ontario; and it is the line preventing the region and the two countries from fully realizing their economic potential.

\section{THE POST-SEPTEMBER 11 THICKENING OF THE US-CANADA BORDER}

On September 11 Detroiters quickly realized just how important the existing Detroit-Windsor bridge was for the region's integrated automotive economy. The terrorist attacks brought commerce to a screeching halt with immediate increases in security checks and more stringent travel and cargo documentation requirements. While the most onerous of these requirements were eventually lifted, there remained a post-September 11 "thickening" of the US-Canada border that made it harder for legitimate trade and travel with our largest trade and tourism partner.

In 2011 US President Obama and Canadian Prime Minister Harper rightly recognized the onerous costs of the border-conservatively estimated at $\$ 10$ billion a year of additional expenses due to inspection delays, paperwork requirements, and regulatory differences-and announced initiatives that would make it easier for goods and people to cross. At the same time, Michigan's Governor Snyder was considering building a new bridge across the said border crossing, and Congressman Peters was looking

Matthew K. Asada served as a 2011-2012 American Political Science Association Congressional Fellow with US Representative Gary Peters from Michigan. Mr. Asada is currently mentoring the nation's next generation of diplomats and assigning them to their first couple of tours. He previously served in border posts in South Asia (Kolkata, India; Kunduz, Afghanistan; and Lahore, Pakistan) and Europe (Munich, Germany). He can be reached at matthew.asada.who2@wharton.upenn.edu. The views contained in this article are his own and do not necessarily represent those of the United States Department of State or the United States Government. to stimulate economic activity in his district. As an APSA congressional fellow with a background in borders I had arrived on Capitol Hill at just the right time. While the majority of APSA congressional fellowships have a Canadian flavor, given the study trip to Ottawa to compare the Canadian and American legislative systems, I had no idea that my year would be such a Canadian one. By the end of the fellowship I had traveled to Ottawa, Edmonton, Montreal, and Windsor and had developed a newfound appreciation for our closest neighbor, partner, friend, and ally.

\section{MICHIGAN'S NEW 14TH CONGRESSIONAL DISTRICT}

Congressman Peters' new congressional district includes the suburbs, the city of Detroit, and the Detroit-Windsor border with its existing bridge, and vehicle and rail tunnels. The DetroitWindsor corridor is North America's, and arguably the world's, most valuable trade artery linking the industrial basins of Detroit, Chicago, and Cleveland with those of Toronto and Montreal and responsible for more than a quarter of US-Canadian trade. More than $\$ 330$ million in goods crosses the Detroit-Windsor border each day. The border's competitiveness vis-à-vis other crossings, however, has waned recently because of capacity constraints due to aging infrastructure, limited customs plaza space, and inadequate highway connections, especially on the Canadian side.

\section{A NEW INTERNATIONAL TRADE CROSSING}

To reduce transportation costs and improve reliability of the crossing, the Michigan and Ontario governments proposed construction of a second Detroit-Windsor bridge across the Detroit River. After extensive public consultation, they identified a location two miles south of the existing bridge that would connect the new bridge directly with the highway network, thereby avoiding downtown Windsor and its at-grade railroad crossing and 17 street lights-the only street lights on the entire road from Mexico to Montreal! The proposal stalled due to opposition from the owner of the existing bridge, who saw the new bridge as a threat to his Detroit-Windsor trade. However, in 2012 the Governor of Michigan used his executive authority, as provided for in the Michigan Constitution, to sign an agreement with the Government of Canada to build the new bridge in Michigan's new 14th district. Canada-in a testament to the value that it places on the bridge-agreed to advance the capital requirements for the \$2 billion project. The bridge is arguably North America's most important infrastructure project directly linking North America's two largest economies and facilitating trade with the thirdMexico. The project is expected to create roughly 10,0oo new construction jobs in the Michigan-Ontario region and will reinforce Detroit's strategic position as a transportation and logistics 
Figure 1.

\section{Crossing the Detroit River on the Detroit-Windsor truck ferry and looking north toward North America's most valuable border crossing}

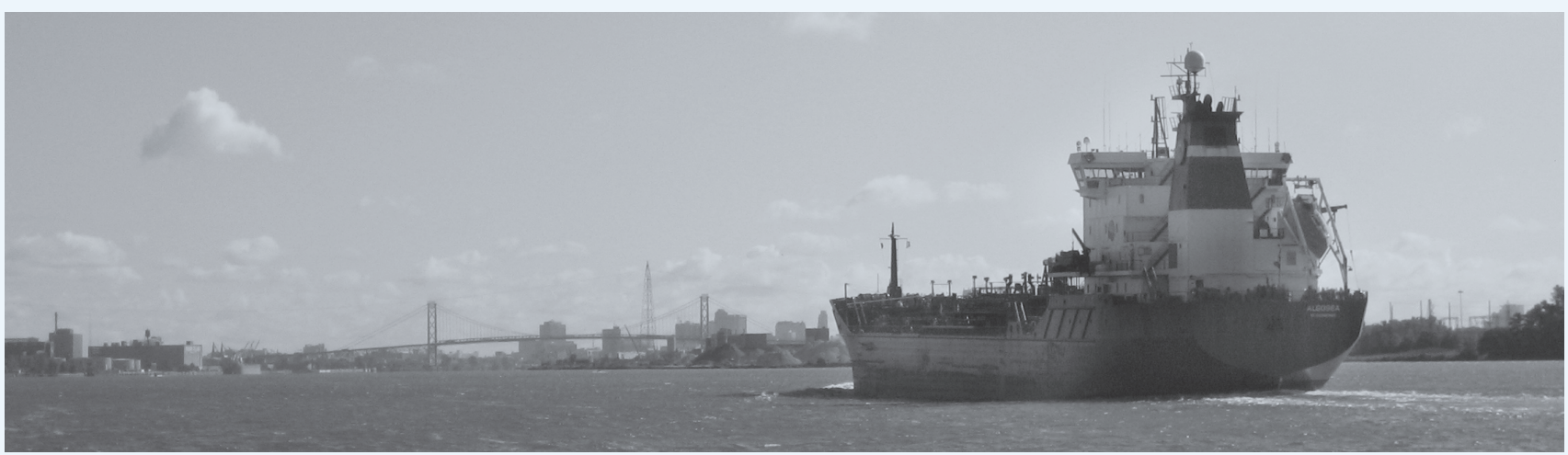

Photo courtesy of Matthew Asada

hub in the 21st century at the heart of the Great Lakes economic region. Although there is still a bit of work to do before the bridge becomes reality (construction is expected to take up to a decade) it was exciting to see Congressman Peters at the bridge's public announcement ceremony last June.

\section{THREE LESSONS FROM ANOTHER BRIDGE}

While working as a fellow in the congressional office, I could not help but think back to a previous bridge project that I had been involved with. Five years prior in Asia I had worked to open and maximize the trade opportunities of the new Afghan-Tajik bridge across the river Amu Darya. This was the first bridge between the two countries linking together what the river, and the Cold War, had kept apart. Although the projects are of vastly different scale both in expense and trade volume (the Detroit-Windsor bridge is 20 times more expensive than the Afghan-Tajik bridge) three lessons are worth sharing: in addition to the actual bridge and customs infrastructure, a successful crossing requires travel documentation issuance facilities, well-trained customs personnel, and local binational political cooperation.

\section{Visa-Issuing Consulate}

The first lesson is that it needs to be easy and convenient for travelers to obtain travel documents. In Afghanistan, the lack of a Tajik Consulate in Kunduz-the Afghan city closest to the new bridge-required Afghans to travel more than four hours by car each way for a visa to make the journey across the bridge. Similarly, the lack of an American consulate in Windsor requires non-Canadian citizen residents requiring a visa (Canadian citizens do not require a visa) to travel more than four hours by car to Toronto, eight hours roundtrip, to cross the Detroit river. For those of you from New York City, this would be similar to requiring an employee living in Manhattan to travel to Washington, DC, to get a visa to cross the East River to visit a friend in Queens!

I was surprised that the United States did not have a visaissuing consulate in Windsor. When I visited the National Archives in College Park, Maryland, I learned that the United States, in fact, previously had a diplomatic presence in Windsor for more than 100 years, but in 1970 it closed the consulate because of an austerity program and budgetary constraints. Today, Canada has an increasing number of non-Canadian resident immigrants all of whom require visas to cross the river from Windsor to Detroit. We should be doing everything we can to make it easier, not harder, for Canadian residents to visit the United States for legitimate trade and travel purposes. During the year, I learned that an American consulate in Windsor would cost less than a couple million dollars a year to operate and would issue more visas and stimulate more trade than at least two of the existing American visa issuance facilities in Canada. In an editorial placed with the local newspaper, the Detroit News, Congressman Peters proposed re-opening a US Consulate in Windsor.

\section{Trained Customs and Border Personnel}

The second lesson from my bridge-building experience in Afghanistan is the need for well-trained customs and border personnel to operate the crossing. The Afghan and Tajik governments had never operated an international bridge before and were instead accustomed to the daily ferry crossings that would intermittently transport up to 40 trucks a day. In comparison, the new Afghan-Tajik bridge promised a maximum capacity of 1,00o trucks a day crossing continuously. The infrastructure was the easy part-building up the human capacity to operate the crossing was harder. While the Americans and Canadians are used to operating the existing Detroit-Windsor bridge, albeit with vastly undersized customs and inspection plazas, there is still a need for personnel to focus on increased trade and travel facilitation. In speaking with the US Department of Homeland Security I learned that there was no Center of Excellence that focused on trade and travel facilitation on the northern border. I looked into how a center might be established and funded. Congressman Peters has since proposed such a center in Detroit to work with a newly launched Canadian center in Windsor to identify joint solutions and best practices for what promises to be a 21st century model land port of entry.

\section{Local Binational Political Cooperation}

The third lesson is the importance not only of high-level head of state/government cooperation, but local binational bipartisan political cooperation. In the highly centralized governments of Afghanistan and Tajikistan President Karzai and President 
Rakhmon's decision may have been enough to build the new bridge, but it required local cooperation and engagement at the bridge site itself to agree to the actual opening times and arrangements. In the American presidential and Canadian parliamentary democratic systems, local binational and bipartisan cooperation between the federal representatives is just as important as that between President Obama and Prime Minister Harper given the profile of the bridge and importance of local buy-in. Congressman Peters worked closely with his Democratic and Republican colleagues, and Canadian Government and Opposition parliamentary counterparts, to build support for and increase public reporting requirements for pleasure boaters. Given the extensive interior coastline, many Michigan and Ontario residents enjoy boating on the lakes and often unknowingly cross the undefined maritime border. The United States and Canada had historically observed a "no landing, no reporting" requirement, that is, if a boater was fishing in the lake and crossed the international border, but did not land on the other side, the individual did not have to report to either country as having arrived or departed. However, last year the Canadians began enforcing a standing, but regularly overlooked, reporting requirement thus triggering a reciprocal American reporting requirement. Reinstituting a "no

\section{Just as France and Germany are the engines of Europe's economic activity, so too are Michigan and Ontario the manufacturing motors of North America.}

awareness of the border initiatives. I traveled to Detroit several times to organize an event with the Detroit Regional Chamber to promote greater binational cooperation. The event occurred a week after the public announcement of the new bridge in a room appropriately overlooking Detroit, Windsor, and the Detroit River.

\section{TRUSTED TRAVELERS}

One of the most valuable and enjoyable parts of the congressional fellowship was interacting with constituents. It was often from constituents that the best policy ideas were born or the more egregious ones were highlighted. While the American and Canadian governments have taken steps to make it easier for trusted travelers, those preregistered with the government, to cross the border through dedicated clearance lanes at land and air ports of entry, further work is needed. One area ripe for cooperation-brought to the Congressman's attention by a constituent-is landing, no reporting" requirement would improve the quality of life, and the quality of boating, for Americans and Canadians on both sides of the border.

In the course of my fellowship with Congressman Peters, I gained a much better appreciation for our northern neighbor and its importance to our own economic development. Just as France and Germany are the engines of Europe's economic activity, so too are Michigan and Ontario the manufacturing motors of North America. We need to make it easier, not harder, for our citizens to create businesses and trade with one another to be the North American powerhouse that can compete globally with Europe, Asia, and the rest of the world in the 21st century. Detroit and Windsor are unlike any other two cities in North America whose downtowns may be physically separated by a river, but whose people, companies, and families are tightly integrated and may, in the future, be connected by a new bridge running through US Representative Gary Peters' 14th congressional district. 